\title{
The Influence of Financial Literacy and Environmental on Student Intentions for Social Entrepreneurship
}

\author{
(Case Study at Nusa Putra University)
}

\author{
Heliani ${ }^{1}$, "Vina Herdina ${ }^{2}$, Siti Hasna Fadhilah ${ }^{3}$, Risma Yulianti ${ }^{4}$ \\ ${ }^{1}$ Lecture in Nusa Putra University, Sukabumi, Indonesia \\ ${ }^{2}$ Student in Nusa Putra University, Sukabumi, Indonesia \\ ${ }^{3}$ Student in Nusa Putra University, Sukabumi, Indonesia \\ ${ }^{4}$ Student in Nusa Putra University, Sukabumi, Indonesia \\ *Corresponding author.Email: vina.herdina ak19@nusaputra.ac.id
}

\begin{abstract}
Student intentions for entrepreneurship can be said as the intention or desire of a student to run an entrepreneur. This research aims to determine how financial literacy and the environment affect students' intentions to engage in social entrepreneurship at Nusa Putra University. There were 170 respondents in this study, all of whom were undergraduate students at The University of Nusa Putra who studied a variety of majors. The hypothesis test used is a multiple linear regression test to see the influence between dependent variables and independent variables. The findings of this study show that financial literacy and their respective environments impact students' intentions to participate in social entrepreneurship.
\end{abstract}

Keywords: Student Intentions, Financial Literacy, Environment.

\section{INTRODUCTION}

Things of an economic nature such as increasing employment opportunities, profits, and market share have been a significant focus in the growth of commercial enterprises. However, experts, practitioners, and policymakers are beginning to shift the main focus of economic growth to broader motivations related to the creation and growth of businesses through social entrepreneurship [1]. Social enterprises carry a wide variety of activities, including environment, advocacy, and activism [2]. Compared to commercial enterprises, social enterprises face various complex growth barriers, as social enterprises have a dual mission to achieve economic and social creation. Worldwide, social enterprises have the potential to confront and address the most complex and challenging problems in society arising from the failure or inadequacy of governments and markets [3]. Minimal resources and environments contribute significantly to the emergence of social entrepreneurship organizations. Social enterprises operate in various fields, including environmental protection and sustainability, regional development, education, health and care services, human rights, and work integration.

Student intentions for entrepreneurship can be said as the intention or desire of a student to run an entrepreneur. To run a business must undoubtedly be started with intention. Without high entrepreneurship, a business will not be able to run well. High intentions will result in a firm commitment. Before someone starts a career in entrepreneurship, they must commit to starting it because business performance will be better with exemplary commitment [4]. Financial literacy and environmental conditions are two characteristics that significantly impact solid entrepreneurial inclinations. Financial literacy is related to a person's ability to manage personal finances. Knowledge of financial literacy is significant for everyone, especially students because by knowing financial literacy, students will not be wrong in making decisions about their finances [5]. 
The benefits of financial literacy are one of them in making financial planning for entrepreneurship[6] stated that financial literacy affects entrepreneurship intentions. The higher the financial literacy that a student has, the greater the student's intention to entrepreneurship.

[7] Also states that environmental factors such as support and influence from the environment affect entrepreneurship intentions. Students' intentions for entrepreneurship are certainly influenced by various factors, one of which is environmental factors, such as the university environment and family environment. The entrepreneurship interest cannot be separated from the influence of environmental factors. Students as agents of change become an essential resource in advancing Indonesian entrepreneurship. The intention of students to have a business indeed cannot be separated from the role of entrepreneurial education at the university [8]. Social entrepreneurship education in Indonesia has been carried out in "Merdeka Belajar" by Nadiem Makarim (Minister of Education and Culture). According to [9], as many as $69.1 \%$ of millennials in Indonesia are interested in entrepreneurship. However, the entrepreneurial potential is still not well managed. Some researchers claim a link between the environment and entrepreneurship intentions, but not so strong. However, [10] explains a strong relationship between the environment and entrepreneurship intentions.

This study tries to explain the impact of financial literacy and the environment on Nusa Putra University students' ambitions for social entrepreneurship from the description above. There are several important points as to why this research is essential. First, most of the existing literature on entrepreneurship interests is interest in general, not devoted to social entrepreneurship. Some of the dimensions between literacy and the environment differ significantly in various researchers. Second, social entrepreneurship interest determines the success of programs run by incubators, accelerators, or communities and governments. This cannot be separated from solid factors in the success of social efforts in answering various problems of society and the environment.

Social entrepreneurship intentions, especially the modeling, need to be developed. In this study, the dimension of financial literacy was added to become one of the dimensions of these variables. In addition, we will also marry several overlapping dimensions from various other studies so that there is a complete definition of the intended environmental variable.

\section{LITERATURE REVIEW}

\subsection{Financial Behavior Theory}

Financial behavior is a theory that studies how humans behave in a financial determination. Especially to study how psychology influences financial decisions, companies, and financial markets [11]. The science of how humans respond to and react to available information to make decisions that optimize the rate of return risks is known as financial behavior [12]. [13] states that financial behavior is influenced by several factors, namely financial literacy, numeracy, and quality of education.

\subsection{Planned Behavior Theory}

Planned Behavior theory is a theory [14] that predicts behavioral considerations because behavior can be considered and planned. This theory can identify a person's belief in control over something that will occur due to behavior so that there will be a difference between a person's behavior will and willlessness [15]. [14] suggest that attitude toward behavior, subjective norm, and perceived behavioral control are all components of planned behavior. This theory explains that intention is the main key to predicting human behavior and as a psychological construct that demonstrates the power of one's motivation in terms of conscious planning to produce the behavior in question.

\subsection{Social Entrepreneurship Intentions}

Social entrepreneurship intention is a determination to do entrepreneurship by looking for information that can be used to achieve the goal of forming a business that is useful for the social environment. Social entrepreneurship intentions are built by desires, preferences, plans, and behavior expectancies [16]. Desires can be defined as the interests that arise in a person is a desire to do entrepreneurship or social entrepreneurship. Preferences can be defined as a person's thinking about entrepreneurship, where he considers that entrepreneurship is a thing or need that needs to be achieved. Plans are a person's plan about his desire to do a business in the future. Meanwhile, behavior expectations are a possibility to start a business initiated by the desire by making business targets that must be achieved in the future. 


\subsection{Financial Literacy}

[17] Financial literacy is the ability to manage one's finances to have a happy and wealthy life in the future. Financial literacy is done to provide knowledge on how to manage finances intelligently and not be easily manipulated by financial packages that promise high long-term gains. Financial literacy is very important for a student because it is beneficial for managing personal finances and for managing the business owned when students decide to be entrepreneurial. Often newly built entrepreneurs fail in a fast time due to a lack of financial literacy. Therefore, we need to know financial literacy. [18] financial literacy can be measured using 4 (four) indicators, namely:

\subsubsection{General Knowledge of Personal Finance}

This knowledge manifests itself in the capacity to handle personal funds and apply effective management to attain personal objectives. A student should know the general knowledge of personal finance well, such as allocating funds owned, including purchasing decisions in the daily scope, planning for the future, and responding to events that occur daily in the economy in general [19].

\subsubsection{Deposits and Loans}

Savings are setting aside some income to store and can be used at any time. A loan is a type of debt that involves all kinds of natural objects.

\subsubsection{Insurance}

Insurance is a premium payment agreement between the insurance company and the policyholder in exchange for replacing the damages that have been agreed upon.

\subsubsection{Investment}

Investment is the activity carried out by investors by buying stocks, bonds, or other letters to a company for increased wealth.

Low levels of financial literacy are a severe problem because they can negatively impact financial behavior. In addition, it will also make the worry faced even more significant due to the birth of new financial mechanisms and products and their increasingly complex offspring [20].

\subsection{Environment}

The environment is the place of interaction between individuals and other individuals. The environment can be a contributing factor to entrepreneurship [21]. Many factors affect student intentions in entrepreneurship. One of them is environmental factors, such as family environment, university environment, and social environment [22]. The scope of the university or education environment becomes one of the institutions that have an essential role in efforts to form resilient entrepreneurs [23]. Entrepreneurial education can provide insight to its students into the entrepreneurial world and motivate students to foster strong interest and intention to build an entrepreneur so that students as agents of change can be realized as an improvement of the country's economy through entrepreneurship. At the same time, the family environment is the first and foremost media that affects child development behavior [24]. The support of parents and relatives, businesses owned by the family, and other factors in the family environment are also expected to affect students' intention in social entrepreneurship.

\subsection{Hypothesis}

\subsubsection{The Effect of Financial Literacy on Social Entrepreneurship Intentions}

Financial literacy has a broad meaning, so there is no consensus on the definition of financial literacy [28]. [29] state that financial literacy is a blend of business and financial awareness and knowledge, financial ability, financial management, and planning. Finance. Previous research has shown that the influence of financial literacy on entrepreneurship intentions is minimal. Entrepreneurship knowledge, one of which is the understanding (literacy) of financial management, affects entrepreneurship interest in students [30]. [31] showed that the higher the level of financial literacy in entrepreneurs just starting, the better their chances of survival. Therefore, researchers propose the following hypothesis.

$\mathrm{H}_{1}=$ Financial literacy affects social entrepreneurship intentions

\subsubsection{Environmental Influence on Social Entrepreneurship Intentions}

The environment is a collection of various conditions and outside influences on the development of an organization [32]. These conditions affect behavior, growth, development, or life processes [33]. The environment referred to in this study is the family and university environment. The family environment is the first environment that will profoundly influence a child [34]. At the same time, the university environment is an environment where learners are accustomed to the values of learning so that learners can develop their potential optimally [35].

[36] suggests that the environment affects entrepreneurial interests. In addition, [35] also revealed positive and significant influences of environmental variables on entrepreneurship 
intentions in e-business. Therefore, researchers propose the following hypothesis.

$\mathrm{H}_{2}=$ Environment affects social entrepreneurship intentions

\subsubsection{The Impact of Financial and Environmental Literacy on Social Entrepreneurship Intentions}

Based on [14] in the theory of planned behavior states that interest is influenced by several factors, including attitudes toward conduct, subjective standards, and behavioral control, which are explored in further depth in this study using financial and environmental literacy variables. [37] The theory of planned behavior, which includes attitudes toward behavior, subjective norms, and perceived behavioral control, can help people start businesses. Therefore, researchers propose the following hypothesis.

$\mathrm{H}_{3}=$ literacy and environment affect the intention of social entrepreneurship

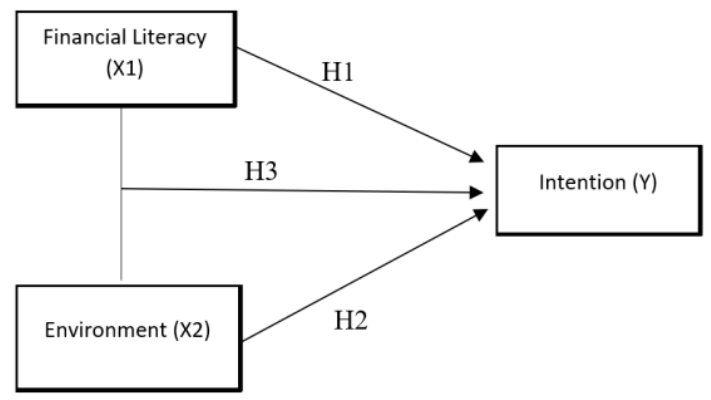

Figure 1. Frame of Mind

\section{RESEARCH METHODS}

This study takes a descriptive approach and employs quantitative approaches. [25] states that quantitative research methods are used to examine a particular population or sample. The location of this study is The University of Nusa Putra, with the population being students of The University of Nusa Putra who are doing education at strata one (S1). Data were collected by distributing online questionnaires and connected using google documents. In determining sample units, purposive sampling techniques are used with several criteria used in research [26], namely 1) male and female students are studying S1, and 2) are studying at the university. Nusa Putra University. In general, the sample size will affect the strength of the statistics. According to [27], the sample count is at least 5 times the number of indicators. In addition, [27] also suggested that the appropriate sample size was between 100-200 respondents. In this study, the sample number of 170 respondents was felt to be enough to represent the population. The respondents consisted of each study program located at the University of Nusa Putra.

Statistical Package for the Social Sciences is hereinafter referred to as SPSS, used to look for influences between variables on quantitative methods, then as a tool in the processing of qualitative data derived from interview results with open mode questionnaires from informants, which are ultimately used as supporting data for more comprehensive analysis. Microsoft Excel applications are used to analyze descriptive variables as qualitative data processing. The method used to develop an equation that can explain the relationship between independent variables and dependent variables using regression, with the following formulas:

$$
Y=a+b_{1} X_{1}+b_{2} X_{2}+e
$$

Descriptions:

$$
\begin{array}{ll}
\mathrm{Y} & =\text { Intention of Social Entrepreneurship } \\
\mathrm{a} & =\text { Constant } \\
\mathrm{b}_{1}, \mathrm{~b}_{2} & =\text { Regression coefficient } \\
\mathrm{X}_{1} & =\text { Financial Literacy } \\
\mathrm{X}_{2} & =\text { Environment } \\
\mathrm{e} & =\text { Error }
\end{array}
$$

\section{DISCUSSIONS}

\subsection{Research Instrument Test}

\subsubsection{Variable Validity Test}

\section{1) Variable Validity Test $X_{1}$}

For all numbers with $\mathrm{R}$ table 0,1266 and all questionnaire items are valid.

\section{2) Variable Validity Test $X_{2}$}

For all numbers with $\mathrm{R}$ table 0,1266 and all questionnaire items are valid.

\section{3) Variable Validity Test $Y$}

For all numbers with $\mathrm{R}$ table 0,1266 and all questionnaire items are valid.

\subsubsection{Reliability Test}

Table 1. Data Realibility Test

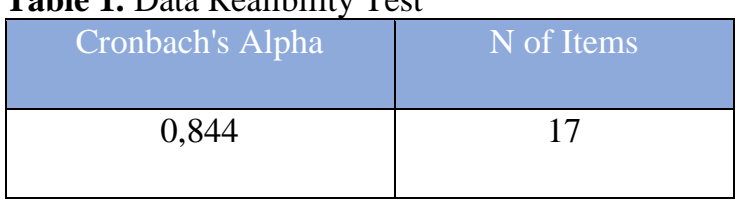

Based on the table above, the value of Cronbach's Alpha of $0.844>0,70$ then the basis of decision making if the alpha value is more than 0,70 is reliable 
[38]. It can be stated that the questionnaire's 17 question items are all reliable or consistent.

\subsection{Classic Assumption Test}

\subsubsection{Residual Normality Test}

Table 2. Residual Normality Test

\begin{tabular}{|l|l|}
\hline \multicolumn{2}{|c|}{ One-Sample Kolmogorov-Smirnov Test } \\
\hline Asymp. Sig. (2-tailed) & 0,200 \\
\hline
\end{tabular}

Based on sig value. The sig value can be seen in the table above. The residual value is 0.200 It can be concluded that the data is normal distribution because the p-value is more than 0.05 [39].

\subsubsection{Multicollinearity Test}

Table 3. Muticollinearity Test

\begin{tabular}{|l|l|}
\hline Tolerance & VIF \\
\hline 0,806 & 1,240 \\
\hline
\end{tabular}

Source: Processed Data, 2021

Based on the table above, the tolerance value is $0.806>0.01$, while the VIF value is obtained at 1,240 $<$ 10. VIF value < 10, meaning there is no multicollinearity [39]. Based on tolerance values and VIF values, It can be concluded that this study shows no signs of independent variable multicollinearity.

\subsubsection{Heteroskedasticity Test}

Table 4. Data Heteroskedasticity Test

\begin{tabular}{|l|l|l|l|}
\hline Type & Constant & $\mathrm{X} 1$ & $\mathrm{X} 2$ \\
\hline t value & 1,370 & 0,683 & $-0,745$ \\
\hline Sig. & 0,173 & 0,496 & 0,457 \\
\hline
\end{tabular}

If the p-value (sig.) $>0.05$ then there is no heteroskedasticity [39]. According to the table above, variable X1 has a p-value of $0.496>0.05$, indicating that there are no symptoms of neuroplasticity. The X2 variable has a Sig value. $0.457>0.05$, meaning there are no symptoms of neuroplasticity. So it can be concluded that there are no symptoms of heteroscedasticity on both independent variables.

\subsection{Multiple Linear Regression}

Table 5. Miltiple Linear Regression Test

\begin{tabular}{|l|l|l|l|}
\hline Type & Constant & Total X1 & Total X2 \\
\hline B & 8,262 & 0,316 & 1,032 \\
\hline Std. Error & 2,581 & 0,139 & 0,172 \\
\hline
\end{tabular}

Source: Processed Data, 2021

Based on the multiple linear regression test table with SPSS, the regression model is obtained as follows:

$\mathrm{Y}=8,262+0.316$ Financial literacy $+1,032$

Environment $+\mathrm{e}$

The regression coefficient for the Financial Literacy variable (X1) is 0.316 , and the Environment variable (X2) is 1.032. The regression coefficient $\mathrm{X} 1$ is positive, meaning that when variable $\mathrm{X} 1$ rises by 1 unit, then $\mathrm{Y}$ rises by 0.316 and vice versa. The regression coefficient of $\mathrm{X} 2$ is 1.032 and is marked positive, meaning that when the $\mathrm{X} 2$ variable rises by 1 unit, then variable $\mathrm{Y}$ will also rise by 1,032 and vice versa.

\subsection{Hypothesis Test}

\subsubsection{Simultaneous F Test}

Table 6. Simultaneous F Test

\begin{tabular}{|l|l|}
\hline $\mathrm{f}$ Value & Sig. \\
\hline 32,903 & 0,000 \\
\hline
\end{tabular}

\subsubsection{Partial t-Test}

Table 7. Partial t-Test

\begin{tabular}{|l|l|l|l|}
\hline Type & Constant & $\mathrm{X} 1$ & $\mathrm{X} 2$ \\
\hline $\mathrm{t}$ value & 3,200 & 2,262 & 5,999 \\
\hline Sig. & 0,002 & 0,025 & 0,000 \\
\hline
\end{tabular}

Suppose the value $t$ calculates the $>t$ of the table and the sig value. $<0.05$, the accepted hypothesis means that significant regression coefficients or independent variables significantly influence dependent variables [40]. 


\subsection{Results}

\subsubsection{Results of The Impact of Financial Literacy on Social Entrepreneurship Intentions}

The $\mathrm{t}$ value for variable $\mathrm{X} 1$ is $2,262>\mathrm{t}$ table is 1.97 , and the Sig value is obtained by 0.025 based on the table above. So H1 is accepted, the financial literacy variable positively affects student intentions for social entrepreneurship, according to the findings. This is consistent with earlier studies conducted by [41], [42], and [6], which stated that Financial Literacy affects student intentions for entrepreneurship. This is because the higher the level of financial literacy knowledge, the higher the interest in entrepreneurship. This result is also in line with the theory of financial behavior [12] that the availability of optimal information to make decisions that can optimize the level of Returns will make entrepreneurship interest even higher.

\subsubsection{Results of Environmental Influence Tests on Social Entrepreneurship Intentions}

The value $\mathrm{t}$ value for variable $\mathrm{X} 2$ is $5,999>\mathrm{t}$ table is 1.97 , and the sig value is 0.000 . So $\mathrm{H} 2$ is accepted, so it can be concluded that environmental variables positively affect student intentions for social entrepreneurship. This is consistent with earlier studies conducted by [35], [36], [43], which stated that the environment affects entrepreneurship intentions. These results are also in line with the planned behavior theory [14] that interests are influenced by attitudes toward behavior, subjective norms, and behavioral control. This study is more specific by using environmental variables that affect the development of individuals. A person who grows up in an entrepreneurial environment will have a relatively greater chance of becoming an entrepreneur.

\subsubsection{Results of Tests on The Influence of Financial and Environmental Literacy on Social Entrepreneurship Intentions}

To see the influence of financial literacy and the environment on social entrepreneurship intentions, simultaneous test $\mathrm{F}$ was conducted to see its influence simultaneously. If the value $\mathrm{F}$ calculates the $>\mathrm{F}$ of the table or the probability < the sig value. Then the research model can be used [40]. Based on the table above the value $\mathrm{F}$ calculated $32,903>\mathrm{F}$ table which is 3.05 and sig value of $0.00<0.05$. It can then be concluded that $\mathrm{H} 3$ is accepted, based on the $\mathrm{F}$ test variables $\mathrm{X} 1$ and $\mathrm{X} 2$ have a significant effect simultaneously on variable $\mathrm{Y}$. This is consistent with the theory of planned behavior, which consists of three components: attitude toward behavior, subjective norm, and perceived behavioral control, all of which are more specifically defined by financial literacy and environmental circumstances. A high level of financial literacy accompanied by an environment that supports entrepreneurship will cause interest in social entrepreneurship.

\section{CONCLUSION}

The results revealed that literacy affects social entrepreneurship intentions and that environment affects the intention of entrepreneurship and financial and environmental literacy simultaneously. Influence on the intention of social entrepreneurship at the University of Nusa Putra. The researcher's suggestion to the next researcher is expected to increase the study's population and variables, resulting in more diverse data.

\section{AUTHORS' CONTRIBUTIONS}

$\mathrm{H}$ coordinates the research, oversees the research, helps analyze and interpret data, helps evaluate research results. VH determines research components or instruments, coordinates data collection, interprets research data, and assists in submitting scientific articles. SHF assists with data analysis and interpretation to help search literature studies. RY prepares data and processing, helps find literature studies, helps design research concepts.

Description:

H: Heliani

VH: Vina Herdina

SHF: Siti Hasna Fadhilah

RY: Risma Yulianti

\section{ACKNOWLEDGMENTS}

We would like to thank the supervisors who have helped in completing this research and the respondents who have been willing to take the time to fill out the questionnaire.

\section{REFERENCES}

[1] D. Sarpong and C. Davies, "Managerial organizing practices and legitimacy seeking in social enterprises," Social Enterprise Journal, vol. 10, no. 1, pp. 21-37, Apr. 2014, DOI: 10.1108/sej-05-2013-0019.

[2] K. Nicolopoulou et al., "Questioning the Legitimacy of Social Enterprises through Gramscian and Bourdieusian Perspectives: The Case of British Social Enterprises," Journal of Social Entrepreneurship, vol. 6, no. 
2, pp. 161-185, May 2015, DOI: 10.1080/19420676.2014.961095.

[3] K. Reid and J. Griffith, "Social enterprise mythology: critiquing some assumptions," Social Enterprise Journal, vol. 2, no. 1, pp. 110, Mar. 2006, DOI: $10.1108 / 17508610680000709$.

[4] I. Asri Prastiwi and T. Siwi Agustina, "Latar Belakang Keluarga Wirausaha dan Niat untuk Berwirausaha," Festival Riset Ilmiah Manajemen dan Akuntansi, pp. 578-590, 2019.

[5] F. Margaretha and R. A. Pambudhi, "Tingkat Literasi Keuangan Pada Mahasiswa S-1 Fakultas Ekonomi” Jurnal Manajemen dan Kewirausahaan (Journal of Management and Entrepreneurship), vol. 17, no. 1, Mar. 2015, doi: 10.9744/jmk.17.1.76-85.

[6] B. Elnath Aldi, I. Herdjiono, and G. Maulany, "The Influence of Financial Literacy on Entrepreneurial Intention," Advances in Economics, Business and Management Research (AEBMR), vol. 92, pp. 700-703, 2019.

[7] N. Auwalu Ibrahim, "Environmental Factors And Entrepreneurial Intention Among Nigerian Students In UUM," UTM Press, vol. 5:2, pp. 87-93, 2015, [Online]. Available: www.sainshumanika.utm.my

[8] R. Ningsih, "Peranan Pendidikan Kewirausahaan Dalam Meningkatkan Motivasi Berwirausaha Bagi Mahasiswa" LPPM Universitas Indraprasta PGRI Jakarta, vol. 29, pp. 60-69, 2017.

[9] R. Fiola, "IMR 2019: Mayoritas Millennial Ingin Jadi Pengusaha,” Jan. 19, 2019. https://www.idntimes.com/news/indonesia/ro sa-folia/imr-2019-mayoritas-millennial-inginjadi-pengusaha/1 (accessed Dec. 02, 2021).

[10] C. Mason and J. Barraket, "Understanding social enterprise model development through discursive interpretations of social enterprise policymaking in Australia (2007-2013)," Social Enterprise Journal, vol. 11, no. 2, pp. 138-155, Aug. 2015, DOI: 10.1108/sej-022014-0010.

[11] N. John R, Investment Madness: How Psychology Affects Your Investing and What to Do About It. New Jersey: Practice Hall, 2001.

[12] Lintner, Behavioral Finance: Why Investors Make Bad Decisions. The Planner, 1998.
[13] A. Grohmann, R. Kouwenberg, and L. Menkhoff, "Childhood roots of financial literacy," Journal of Economic Psychology, vol. 51, pp. 114-133, Dec. 2015, doi: 10.1016/j.joep.2015.09.002.

[14] I. Ajzen, "The Theory of Planned Behavior," Organizational Behavior and Human Decision Processes, vol. 50, pp. 179-211, 1991.

[15] L. Wellington, K. M. White, and P. Liossis, "Beliefs underlying intentions to participate in group parenting education," Australian eJournal for the Advancement of Mental Health (AeJAMH), vol. 5, no. 3, 2006, [Online]. Available:

www.auseinet.com/journal/vol5iss3/wellingt on.pdf

[16] M. van Gelderen and P. Jansen, "Autonomy as a start-up motive," Journal of Small Business and Enterprise Development, vol. 13, no. 1, pp. 23-32, 2006, DOI: $10.1108 / 14626000610645289$.

[17] Otoritas Jasa Keuangan (OJK), "Literasi Keuangan," 2013. https://www.ojk.go.id/id/kanal/edukasi-danperlindungan-konsumen/Pages/literasikeuangan.aspx (accessed Dec. 01, 2021).

[18] H. Chen and R. P. Volpe, "An Analysis of Personal Financial Literacy Among College Students," vol. 7, no. 2, pp. 107-128, 1998.

[19] Kusumadyahdewi, "PENGETAHUAN KEUANGAN DI KALANGAN MAHASISWA," Jurnal Pendidikan Ilmu Pengetahuan Sosial, vol. 2, no. 2, pp. 119134, 2016.

[20] O. Viana Sari, "PENGARUH LITERASI KEUANGAN DAN LINGKUNGAN KELUARGA TERHADAP MINAT BERWIRAUSAHA MAHASISWA STKIP YPM BANGKO TAHUN 2018/2019," Jurnal Ekopendia: Jurnal Ekonomi dan Pendidikan, vol. 6:1, pp. 85-95, 2021.

[21] T. Purwinarti, "Faktor pendorong minat berwirausaha (studi lapangan terhadap Politeknik Negeri Jakarta," Jurnal penelitian ekonomi dan bisnis, vol. 5, no. 1, pp. 39-46, 2006.

[22] O. Muladi and W. Staf Pengajar, "PEMBELAJARAN KEWIRAUSAHAAN DAN MINAT WIRAUSAHA LULUSAN SMK," Ekplanasi Volume, vol. 6:2, pp. 109- 
122, 2011, [Online]. Available: http://www.muladi-wibowo.blogspot.com

[23] A. Sarifudin, "Membangun Jiwa Wirausaha Siswa," 2011. SMK.http://aniesmedia.blogspot.com/2011/0 4/membangun-jiwawirausaha-siswasmk.html (accessed Dec. 08, 2021).

[24] D. Setiawan, "Pengaruh Ekspetasi Pendapatan, Lingkungan Keluarga, dan Pendidikan Kewirausahaan terhadap Minat Berwirausaha," 2015.

[25] Sugiyono, Metode Penelitian Pendidikan Pendekatan Kuantitatif, Kualitatif, dan R\&D. Bandung: Alfabeta, 2013.

[26] Sugiyono, Metode Penelitian Kombinasi (Mix Methods). Bandung: Alfabeta, 2015.

[27] J. Hair, Multivariate Data Analysis, 7th ed. United States: Pearson, 2010.

[28] M. Azmi Abdullah and R. Chong, "Financial Literacy: An Exploratory Review of the Literature and Future Research," Journal of Emerging Economies and Islamic Research, vol. 2, no. 3, 2014, [Online]. Available: www.jeeir.com

[29] M. A. Liezl Concepcion-Gallardo, "Financial Literacy and Retirement Preparedness among University of Bohol Employees," vol. 5, 2017.

[30] Banjo G. Roxas, Rhowenna CayocaPanizales, and Rowenna Mae de Jesus, "Entrepreneurial Knowledge and its Effects on Entrepreneurial Intentions: Development of a Conceptual Framework," Asia-Pacific Social Science vol. 8:2, pp. 61-77, 2008.

[31] S. Wise, "The Impact of Financial Literacy on New Venture Survival," International Journal of Business and Management, vol. 8, no. 23, Nov. 2013, DOI: 10.5539/ijbm.v8n23p30.

[32] H. Kusumo, Pengantar Pendidikan. Semarang: IKIP Semarang Press, 1996.

[33] M. N. Purwanto, Psikologi Pendidikan. Bandung: Remaja Rosdakarya, 2000.

[34] S. D. Gunarsa, Psikologi Perkembangan Anak Dan Remaja. Jakarta Pusat: BPK Gunung Mulia, 1983.

[35] U. Uswatun Hasanah, K. Setiaji, J. Pendidikan Ekonomi, and F. Ekonomi, "Economic Education Analysis Journal Terakreditasi SINTA 5 Pengaruh Literasi Digital, Efikasi Diri, Lingkungan Terhadap Intensi
Berwirausaha Mahasiswa Dalam EBusiness," EEAJ, vol. 8, no. 3, pp. 1198-1215, 2019, doi: 10.15294/eeaj.v13i2.17051.

[36] A. Kurniawan, M. Khafid, and A. Pujiati, "Pengaruh Lingkungan Keluarga, Motivasi, Dan Kepribadian Terhadap Minat Wirausaha Melalui Self Efficacy," Journal of Economic Education, vol. 5, no. 1, 2016, [Online]. Available:

http://journal.unnes.ac.id/sju/index.php/jeec

[37] J. Malebana, "Entrepreneurial intentions of South African rural university students: A test of the theory of planned behavior," Journal of Economics and Behavioral Studies, vol. 6, no. 2, pp. 130-143, Feb. 2014, DOI: $10.22610 /$ jebs.v6i2.476.

[38] B. I. H. Nunnally, Psychometric Theory, 3rd ed. New York: McGraw Hill, 1994.

[39] I. Ghozali, Aplikasi Analisis Multivariate dengan Program IBM SPSS 25. Semarang: Badan Penerbit Universitas Diponegoro, 2018.

[40] I. Ghozali, Aplikasi Analisis Multivariete Dengan Program IBM SPSS 23, 8th ed. Semarang: Badan Penerbit Universitas Diponegoro, 2016.

[41] A. Bayrakdaroğlu, "Funda Bayrakdaroğlu A Comparative Analysis Regarding The Effects of Financial Literacy and Digital Literacy on Internet Entrepreneurship Intention *," Kalkınma Dergisi Journal of Entrepreneurship and Development Klş, pp. 27-38, 2017.

[42] F. Adi, U. Sumarwan, and I. Fahmi, "The Influence of Attitude, Subjective Norm, Demography, Socioeconomic and Shariah and Conventional Financial Literacy Toward Entrepreneurship Intention Among College Students," Jurnal Al-Muzara'ah, vol. 5, no. 1, 2017.

[43] F. Kohar, A. Idrus, and S. Pratiwi, "Pengaruh Lingkungan Keluarga Dan Efikasi Diri Terhadap Motivasi Berwirausaha Serta Dampaknya Terhadap Intensi Berwirausaha Mahasiswa Fakultas Keguruan Dan Ilmu Pendidikan (Fkip) Universitas Jambi," vol. 1, no. 4, 2020, doi: 10.31933/JIMT. 